\title{
LOS FUNDAMENTOS DE LA VISUALIDAD DE LA PRUDENCIA
}

THE FOUNDATIONS OF PRUDENCE'S VISUALITY

Maria Montesinos Castañeda

Universitat de València

ABSTRACT: Prudence, as one of the cardinal virtues, is a theme that has been dealt with by numerous thinkers ever since Antiquity. Its broad treatment with regards to different aspects, such as time, governance, selection or advice, has been the object of many visual representations, which show a great variety of attributes, the foundations of which we find in written sources.

KEYWORDS: Prudence, Cardinal Virtues.

RESUMEN: La Prudencia, como parte de las virtudes cardinales, ha sido tema a tratar por diferentes pensadores desde la Antigüedad. Su amplia consideración, en relación a diferentes aspectos, como el tiempo, el gobierno, la elección o el consejo, ha sido fruto de numerosas representaciones visuales que muestran gran variedad de atributos, cuyos fundamentos encontramos en las fuentes escritas.

PALABRAS CLAVES: Prudencia, Virtudes Cardinales. 
La Prudencia, junto con la Fortaleza, Templanza y Justicia, es una virtud que forma parte del pensamiento colectivo desde la Antigüedad. Como fundamento moral, ha sido relacionado numerosas veces con la figura del gobernante, siendo considerada la principal de las virtudes por todas sus características y partes. Dada su importancia, la representación visual y reflexión literaria de dicha virtud es amplia y muy diversa, motivo por el cual tan sólo se citarán algunos pensadores y obras. No obstante, se ha tratado de dilucidar las fuentes en las que se basan las representaciones visuales de la Prudencia.

\section{LA PRUDENCIA EN LA ANTIGÜEDAD}

Desde la Antigüedad, la Prudencia ha sido objeto de reflexión para varios pensadores. Pues junto a la Fortaleza, la Templanza y la Justicia completaba el elenco de virtudes intelectuales, las cuales debía poseer todo ciudadano y, sobre todo, el gobernante. Ya en tiempos de Sócrates (470-399 a. C.) existen reflexiones al respecto, recogidas, más tarde, por Platón (ca.427-347 a. C.) y Aristóteles (384-322 a. C.), como se muestra en varios de sus textos. Según Platón, la Prudencia es un sano juicio que no afecta a ninguna actividad determinada, pero sólo porque se aplica a todas las materias humanas. Por este motivo, dicha virtud es propia del gobernante y esencia de la ciudad perfecta (Pl. R. IV; 427e). Concretando la definición platónica, Aristóteles se refiere a la Prudencia de la siguiente manera: «Parece propio del hombre prudente el poder discurrir bien sobre lo que es bueno y conveniente para él mismo, no en sentido parcial, por ejemplo, para la salud, para la fuerza, sino para vivir bien en general» (Arist. EN VI, 5; 1140a 25). Además, Aristóteles indica que la Prudencia no es ni un conocimiento (o ciencia) ni un arte, es un estado o capacidad, es decir, un hábito verdadero razonado para actuar según lo que es bueno o malo para el hombre. Por tanto, en el acto de la Prudencia se delibera sobre lo bueno para el hombre, pero no en particular, sino en cuanto que conduce a la vida buena y feliz en general. De esta manera, la definición aristotélica, contagiada en parte del intelectualismo socrático $y$, por ende, platónico, erige a la Prudencia (phrónesis) a la categoría de virtud dianoética, es decir, intelectual, anteponiéndola en rango a las virtudes morales que pertenecen a la parte irracional, cuya naturaleza es obedecer a la parte racional (León Coloma, 1989: 65).

Partiendo de las premisas dadas, en la reflexión prudente hay dos aspectos a tener en cuenta: el tiempo y la experiencia. A ello se refiere Aristóteles cuando expone que los jóvenes no pueden ser prudentes debido a su falta de experiencia (Arist. EN VI, 9, 1142a 15). De la misma manera, como dicha virtud tiene un fuerte componente social, ya que afecta a todos los individuos, Aristóteles distingue entre dos clases de Prudencia política: una legislativa, propia de los gobernantes, y otra que conserva el nombre común de política y versa sobre los singulares. En ambos casos, dicha virtud es puesta en relación con la providencia (Arist, $E N$ VI, 7; 114la 25) así como con el hecho de aconsejar (Arist. EN VI, 8; 1141b 20-30). Por último, cabe destacar que aunque las traducciones de las fuentes utilicen como sinónimos los términos de "Sabiduría» y "Prudencia», es importante explicar que Aristóteles hizo distinción entre ambos conceptos debido a que la Prudencia se diferencia de la Sabiduría por ser una virtud activa (Arist, EN VI, 5; 1140b 5).

Tras los griegos, Cicerón (106-43 a. C.) y Séneca (4 a. C.- 65 d. C.) adoptaron esta clasificación de las virtudes intelectuales y disertaron sobre el carácter especial de cada una de ellas. Cicerón dedicó todo un tratado, De Officis (44 a. C.), a mostrar el origen, 
las características y la importancia jerárquica de dichas virtudes. En este mismo tratado, Cicerón reconoce como primera virtud a la Prudencia haciendo referencia a su importancia mediante el previo conocimiento de ella por los griegos (CIC. off. 1, 18, 153). Pues, según éste, la Prudencia "consiste en el conocimiento, de las cosas buenas, de las cosas malas, y de las cosas que no son ni buenas ni malas" (CIC. nat. deor. 3, 138), definición que Séneca comparte (SEN. epist. $31,6)$. La elección es la característica más importante que define a la Prudencia, lo que ya destaca Aristóteles y tanto Cicerón como Séneca siguen. Este último, menciona este rasgo numerosas veces: etimológicamente y filosóficamente la Prudencia representa para Cicerón la virtud por excelencia del hombre político (CIC. rep. 6, 1), pues es la primera de las cualidades que ha de tener todo ciudadano (CIC. rep. 5, 10). Al igual que Aristóteles, Cicerón también explica la composición de la Prudencia en diferentes partes (memoria, inteligencia y previsión) que manifiestan la importancia del tiempo en el acto prudente (CIC. inv. 2, 53-160).

Séneca, por su parte, explica la Prudencia como el recuerdo de lo pasado (memoria), la ordenación del presente (inteligencia) y la contemplación del futuro (providencia), por lo que comparte las ideas ciceronianas sobre las partes de dicha virtud. De estas facetas, Séneca destaca con mayor claridad la providencia ya que hace referencia a ella en varias ocasiones: "Más bien evita las cosas que infunden temor, prevé cuanto la Prudencia puede prever, observa y aleja de ti, muchos antes de que suceda, todo cuanto pueda perjudicarte» (SEN. epist. 98, 7). También Ovidio (43 a. C.- 17 d. C.) en sus Fastos (ca. $8 \mathrm{~d}$. C.) hace referencia a la providencia a partir de la imagen literaria de Jano, la cual pasará a ser uno de los rasgos identificativos más importantes de la Prudencia. Pues, ya desde época romana, la bifrontalidad define la imagen del dios Jano, virtualidad fisionómica que le permite observar si-

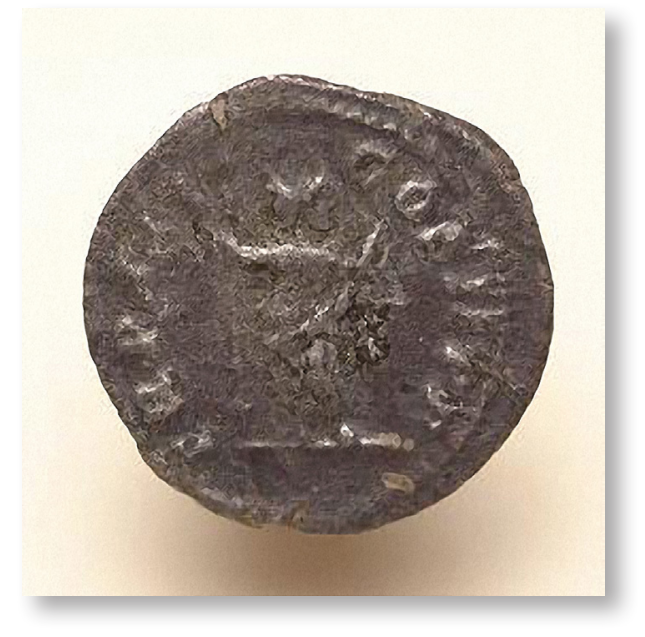

Fig. 1. Jano, Moneda de Septiminio Severo (reverso), 21 1, Mérida, Museo Nacional de Arte Romano.

multáneamente el Oriente y el Poniente, así como el pasado y el futuro, cumpliendo perfectamente con su cometido de portero celestial. Partiendo de dicha consideración, Ovidio (Ov. fast. 1, 89-144) explica la característica bifaz de Jano relacionándola con el físico trifaz de Hécate, aspectos ambos que heredará la imagen de la Prudencia más adelante. Es importante destacar al respecto que el dios Jano fue asociado a la figura del gobernante, al igual que la Prudencia como principal virtud del mismo. Prueba de ello es la representación del dios en el reverso de las monedas romanas, completándose el anverso con la cara del correspondiente emperador [fig. 1].

Más tarde, en el siglo IV, Macrobio también trata la importancia de la Prudencia pues, al igual que los anteriores, destaca el don de la providencia relacionándolo, al igual que Ovidio, a la imagen del dios Jano que se presenta con la cabeza con dos rostros (MACR. Sat. 1, 9, 4). Sin embargo, las Saturnales (ca. 430) de Macrobio son mucho más reveladoras de lo que pudiera desprender esta afirmación, pues en ellas aparece la Prudencia explícitamente asociada a la 
bifrontalidad de Jano (MACR. Sat. 1, 8, 20). Cabe añadir que, además de la providencia y las demás partes enumeradas por dichos pensadores, Séneca relaciona la Prudencia, como novedad, con otro aspecto más, la parsimonia como moderación en los gastos (SEN. epist. 74, 19).

No obstante su amplio tratamiento por pensadores griegos y romanos, las imágenes visuales más antiguas que encontramos de la Prudencia son a través de la representación de diferentes deidades que hacen referencia a dicha virtud. Éste es el caso de la diosa Atenea/Minerva, pues dentro de su correspondiente panteón representaban a la Sabiduría y la Prudencia. A ello hace referencia Ainé cuando explica que en la Antigüedad la Prudencia era llamada Sabiduría, identificada como Minerva/Atenea. Ejemplo de dicha representación es desde la Atenea Parthenos de Fidias hasta las imágenes de Minerva (Ainé, 1850: 53). Cabe destacar que el yelmo, la lechuza y, sobre todo, la serpiente, atributos de dicha diosa, serán, más adelante, atributos propios e identificativos de la Prudencia.

Tras un breve acercamiento a la filosofía antigua ${ }^{1}$ hay que destacar las distinciones y relaciones de la Prudencia con otros conceptos que son importantes, ya que en el desarrollo del artículo encontraremos correspondencia con ellos en el ámbito visual.

\section{LA PRUDENCIA EN LA AN- TIGÜEDAD CRISTIANA Y LA ALTA EDAD MEDIA}

El pensamiento antiguo pasó a la Edad Media prácticamente sin cambios, pues las teorías morales e intelectuales del pasado fueron absorbidas por el cristianismo. Esta asimilación tuvo por fuerza que transparentarse, mediando por supuesto la teología medieval, en la representación de las virtudes y, por tanto, de la Prudencia. Anteriormente ya se ha expuesto cómo Aristóteles había elevado a la Prudencia al rango de virtud intelectual, fundamentándola en la sabia deliberación que nos permite distinguir y diferenciar lo bueno de lo malo. Esta concepción, vigente en el pensamiento romano, como atestiguan las definiciones de Cicerón y Séneca, fue mantenida en el pensamiento medieval materializándose en la representación de la Prudencia, y en concreto en aquellos atributos que tienen un marcado carácter instrumental y que en un plano alegórico procuran el conocimiento (León Coloma, 1989: 74). Las representaciones del concepto son variables ya que encontramos diferentes imágenes que las personifican, dando lugar a una misma alegoría que combina diferentes atributos en cada caso (Maupeu, 2012: 33).

San Ambrosio (340-397) relaciona la Prudencia con el don del consejo así como la figura del gobernante (AMBR. off. 2, 8, 39; PL XVI, 114). Por otra parte, su contemporáneo, san Agustín (354-430) destaca de esta virtud el conocimiento de la verdad (AUg. epist. 60, 6, 9; PL XXXIII, 157), a través de la elección (AUG. gen. ad litt. 8, 14, 32; PL XXXIV, 385) y la providencia (AUg. spec. 4; PL XL, 987). A partir de lo expuesto, san Ambrosio y san Isidoro (556-636) demuestran la continuidad del pensamiento antiguo con el medieval, pues siguen la concepción de dicha virtud como sus predecesores. Además de la definición del término, san Isidoro también destaca la importancia de la providencia como parte de la Prudencia, explicando que el prudente es el que ve de lejos, es perspicaz y prevé con certeza a tra-

1. Existen numerosos estudios filosóficos de la Prudencia en la Antigüedad, algunos de ellos son: Arago Srasser, 1997: 59-84; Aubenque, 1999; Bolaños Larraz, 1958; Carr, 1988: 186-200; Lakatos Janoska, 1994: 57-63; Pierpauli, 2007: 75-101; Sánchez Corredera, 2007: 113-144. 
vés de la incertidumbre de los sucesos (IsID. orig. 1, 10, 201).

Así mismo, siguiendo su interés por las virtudes, san Ambrosio, en De Paradiso, las compara con los cuatro ríos del Paraíso (AMBR. parad. 10, 18; PL XIV, 275), siendo el Pisón que arrastra oro, según Mâle (1986: 147), la Prudencia, imagen que no quedará plasmada hasta el siglo XIII. De la misma manera, san Isidoro de Sevilla en uno de los capítulos de sus Sentencias también hace referencia a dicha correspondencia de los ríos del paraíso con las cuatro virtudes que más adelante serán cardinales (IsID. sent. 2, 1, 14; PL LXXXIII, 191). Por otra parte, san Agustín, siguiendo a Macrobio y Ovidio, defiende al dios Jano en De civitate Dei (412-426), redimiéndolo de las agudas invectivas que dirigió contra los demás dioses del panteón pagano, y habla de Jano como el dios bifronte que mira hacia todas direcciones (Avg. civ. 7, 8.). Esta consecución de la imagen bifaz del dios romano, explica la conexión entre el mundo antiguo y el medieval, pues en este último tendrá lugar la representación visual de la Prudencia con dicho aspecto.

Por otra parte, la Prudencia es tratada junto a las otras virtudes como ente defensivo contra los vicios, lo que inició Aurelio Prudencio (348-410) en su Psycomachia y que numerosos autores siguieron. Es el caso de san Gregorio Magno (540-604), quien presenta a los vicios y a las virtudes como parejas de opuestos en De conflicto vitiorum et virtutum (Mâle, 1986: 117, 1 147). De la misma manera, los poetas carolingios Teodulfo (750-821) y Walafrido Estrabón (808-849) cuentan los combates entre los vicios y las virtudes, lo que también hará, más tarde, Alain de Lille (1116/17-1202/03), que reanuda el mismo tema en el libro noveno de su Anticlaudianus, y Rutebeuf (1230-1285).

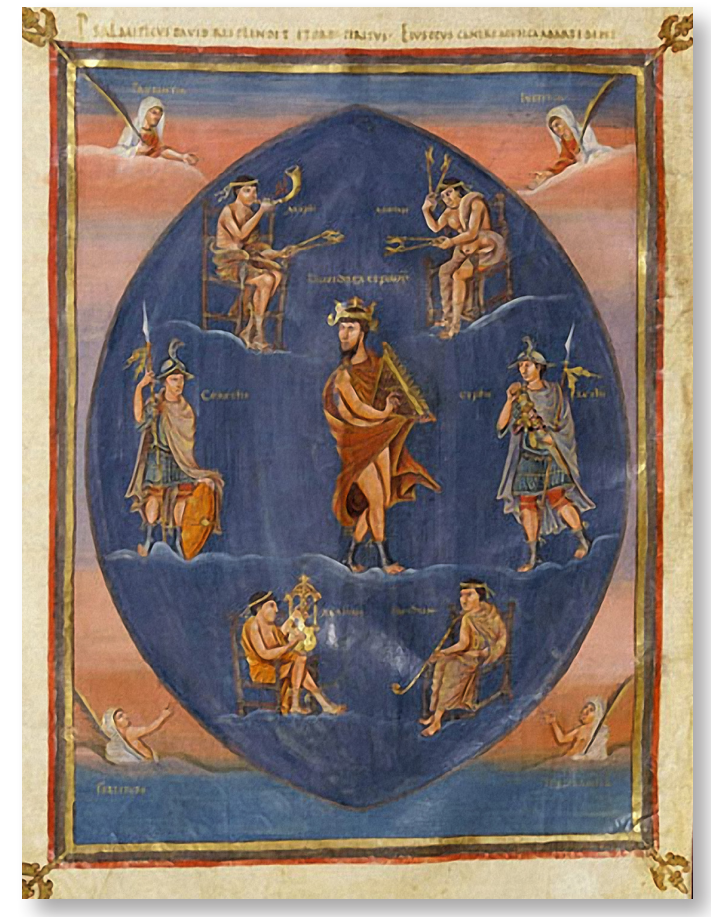

Fig. 2. Justicia, Prudencia, Fortaleza y Templanza, Biblia de Carlos el Calvo, Biblioteca Nacional de Francia.

También Hugo de San Víctor (ca.1096$1141)$ hace referencia a las virtudes cardinales defendiendo su castillo de los ataques de los vicios (De anima, 4, 12.). Cabe destacar que en las ilustraciones de esta obra la Prudencia sostiene un libro (en razón de su sabiduría) (Cames, 1971: 56).

Teodulfo también describe el "árbol de las artes liberales», en el cual menciona a la Prudencia, junto a las otras virtudes cardinales. ${ }^{2}$ Estas mismas asociaciones se encuentran en los escritos de Rabano Mauro (ca.776-856), que quedarán ilustrados en la llamada Biblia de Carlos el Calvo (Biblioteca Nacional de Francia, Manuscrits Latins 1 fol. 215v) [fig. 2]. Hugo de San Víctor, en el siglo XI, presentará dos árboles a los que da nombre a cada una de las ramas. Uno es

2. Aunque la Prudencia, Justicia, Fortaleza y Templanza no son consideradas virtudes cardinales hasta el siglo XIII de la mano de santo Tomás, se hace uso del término para referirse a ellas por ser la denominación empleada actualmente. 


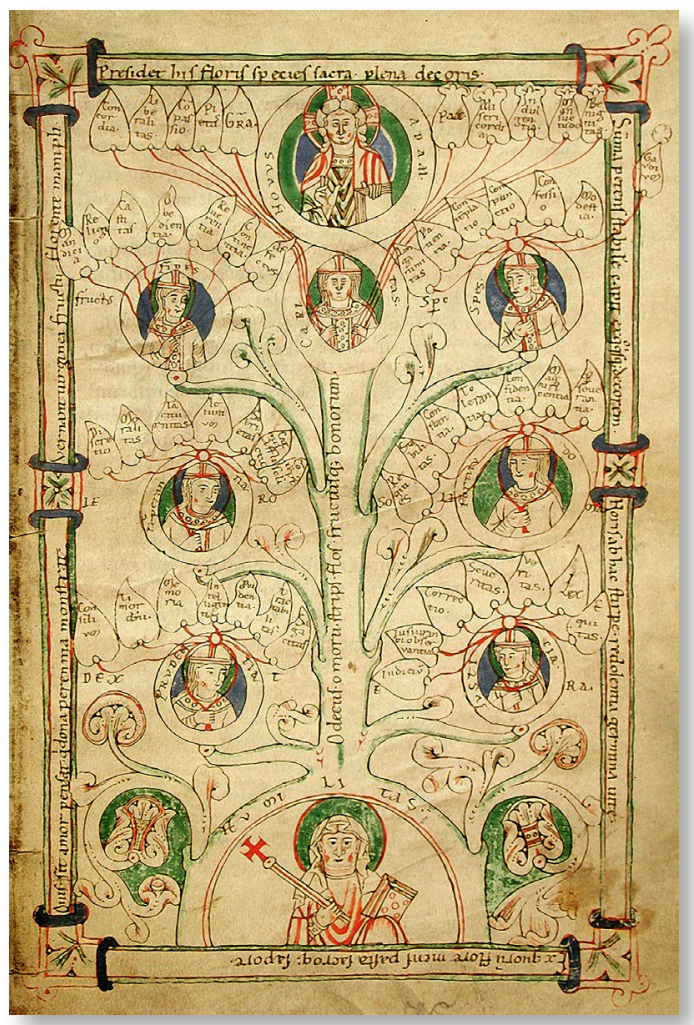

Fig. 3. El árbol de las virtudes, De fructibus carnis et spiritus, s. XII, Salzburg, Studienbibliothek, M.S. Sign. V. I. H. 162 , fol. 76 r.

el árbol viejo de Adán que representa los vicios y el segundo árbol es el del nuevo Adán cuyo tronco es la humildad, y sus siete ramas principales son las virtudes teologales y las cardinales (Mâle, 1986: 119). Dicha representación se encuentra en su obra De fructibus carnis et spiritus en la que encontramos la representación de dicho árbol de las virtudes (s. XII, Studienbibliothek, Salzburg, M.S. Sign. V. I. H. 162, fol. 76r) [fig. 3]. En esta imagen la Prudencia se representa con 7 hojas que hacen alusión a sus partes: Consilium, Timor domini, Memoria, Intelligentia, Providentia, Rationabilitas, Sagacitas.

En la segunda mitad del siglo IX encontramos la imagen de un gobernante junto a las virtudes cardinales (Biblioteca Municipal, Cambrai, MS. 327, fol. 16v.), representándose la Prudencia con un libro, en razón

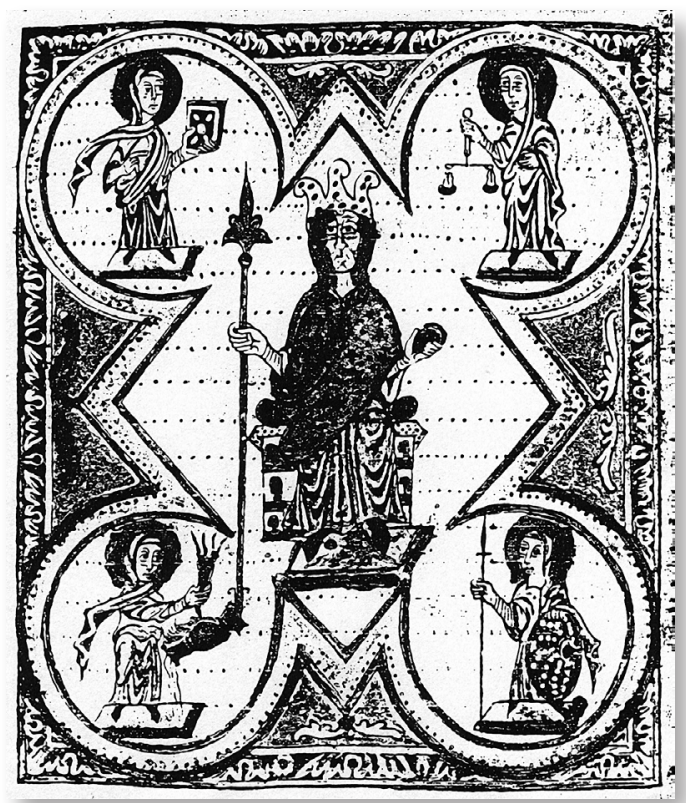

Fig. 4. Gobernante desconocido y las virtudes cardinales, s. IX, Cambrai, Biblioteca Municipal, MS. 327, fol. 16v.

de su sabiduría [fig. 4]. Imagen semejante encontramos en La creación y las virtudes (ca. 1002-1025, Staatsbibliothek, Bayer, Munich. Cod. Lat. 13601, Cim. 54, fol. Iv) y en Enrique II y las virtudes (ca.1014-1024, Biblioteca Vaticana, Roma, Cod. Ottob. Lat. 74, fol. 193v) en las que la Prudencia también porta un libro. Cabe destacar que en esta última imagen aparece la sabiduría en sustitución de la Prudencia, puesto que ambos términos se usaban de forma sinónima ya desde la Antigüedad, lo que demuestra la alusión a ambas mediante las diosa Atenea/ Minerva. De dichas diosas de la Antigüedad toma la imagen de la Prudencia el atributo de la serpiente, como bien muestra la representación del Obispo Frederick y las virtudes cardinales en un leccionario renano (ca. 1130, Biblioteca de la Catedral de Colonia), donde aparece dicha virtud sosteniendo un libro y una serpiente. También en un manuscrito contemporáneo encontramos una ilustración que presenta la conjunción de ambos atributos en la representación de la Prudencia (Nicholas de Verdun, 1181, 


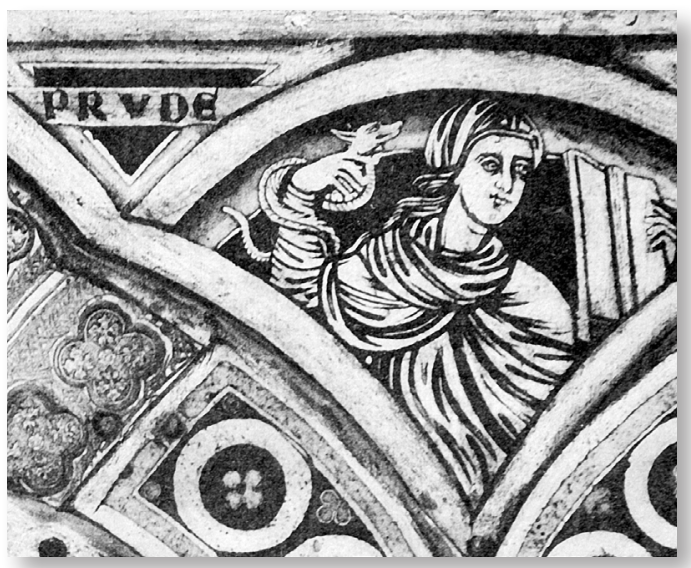

Fig. 5. Prudencia, 1181, Nicholas de Verdun, Klosterneuburg, Stiftsmuseum.

Klosterneuburg, Stiftsmuseum) [fig. 5]. Es destacable que aunque el miniaturista que ilustró el Hortus deliciarum (1167-1185) representó las virtudes en numerosas ocasiones en fila india, con las mismas armas y vestimentas (fol. 200v y 20lv), en los folios 201 y 202 encontramos a la Prudencia enfrontada con la Vanagloria (Cames, 1971: 58-59). No obstante el no distinguirse unas figuras de otras, en esta representación la Prudencia porta un libro (Sebastián, 1988: 291), aunque en otras representaciones de esta misma obra aparece con un basilisco o serpiente (Segura, 2009: 13-14), continuando la tradición visual establecida anteriormente para la imagen de dicha virtud. Además del mundo clásico, las fuentes bíblicas también justifican la presencia de dicho animal, pues san Mateo explica en su Evangelio: "Sed prudentes como las serpientes y sencillos como las palomas» (Mt. 10, 16). No obstante los antecedentes y las fuentes bíblicas que hacen referencia a la serpiente, hay ocasiones en que ésta es interpretada y representada como un dragón. Es el caso de una vidriera del transepto noreste de la Catedral de Canterbury [fig. 6], en la que además de un dragón aparece acompañada de una lechuza, atributo de Atenea/Minerva, lo que confirma la transmisión de imágenes de la Antigüedad a la Edad Media.

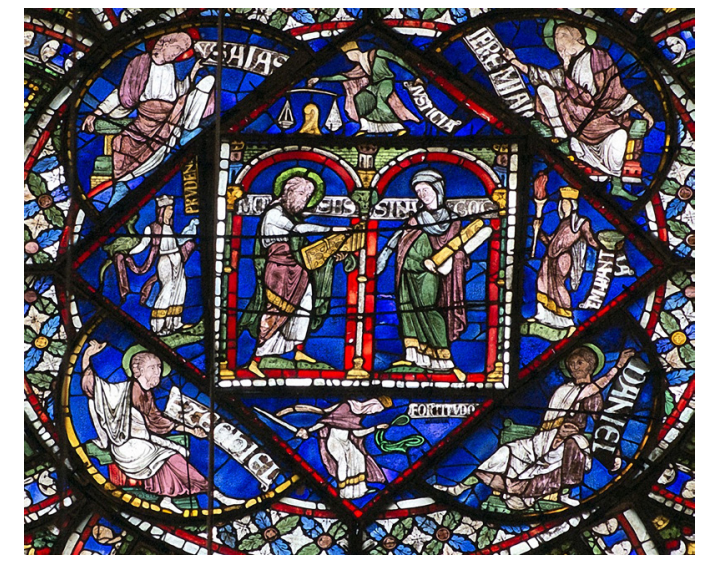

Fig. 6. Virtudes cardinales, Vidriera del transepto este (detalle), 1179-1180, Catedral de Canterbury.

Por último, cabe destacar que en uno de los manuscritos más famosos de la Ética de Aristóteles (s. XII, Bibl. munic. MS. 927), encontramos la representación de la Prudencia, portando un libro, rodeada de cuatro damas con filacterias cuyas inscripciones corresponden a partes de la Prudencia [fig. 7]. Estas damas son la Circunspección, la Providencia, la Precaución y la Docilidad, partes que ya fueron designadas a la Prudencia por los pensadores de la Antigüedad y cuya representación muestra su paso al pensamiento medieval. Otro ejemplo semejante, aunque más tardío, es el sagrario de Orsanmichele (1355-1359, Florencia), en el que Orcagna (1315/1320-1368) representó a la Prudencia acompañada de la docilidad, como parte que la compone (Mâle, 1986: 121).

\section{LA PRUDENCIA EN LA BAJA EDAD MEDIA}

En la Baja Edad Media, los pensadores recogen las ideas de la Antigüedad así como de sus predecesores altomedievales. De esta manera estudian el pensamiento que les precede presentando en sus escritos todo 


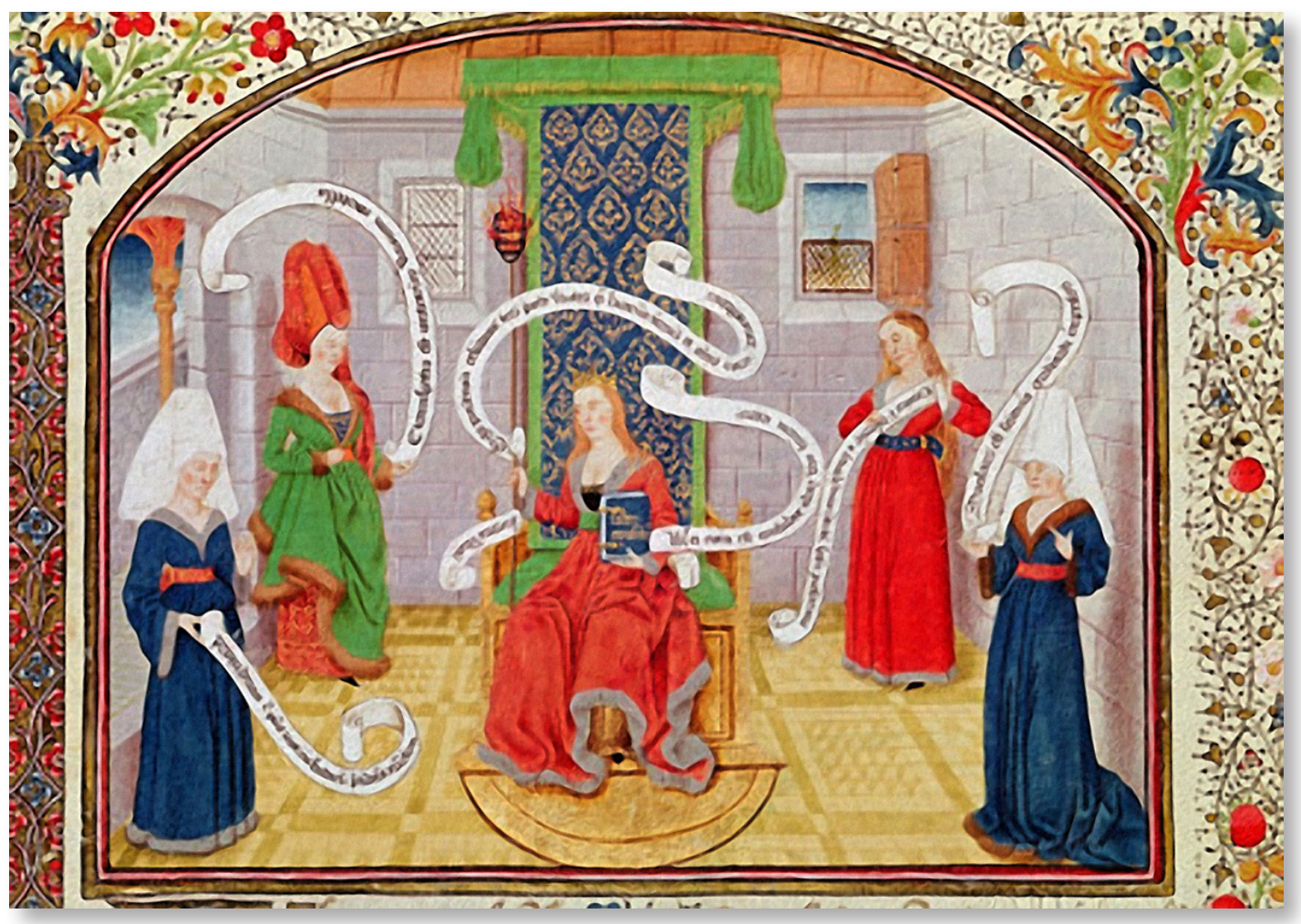

Fig. 7. Prudencia, s. XII, Ética de Aristóteles.

aquello reflexionado sobre la Prudencia y aportando ellos mismos conclusiones al respecto. El caso más importante es el de santo Tomás de Aquino (1224/1225-1274), quien en la Suma Teológica dedica un tratado completo a la Prudencia. En dicho tratado la Prudencia es considerada por primera vez virtud cardinal junto a las otras virtudes que anteriormente eran denominadas intelectuales. A partir de dicha consideración, santo Tomás define la Prudencia como la «sabiduría en el hombre» (S.Th. [40934] II ${ }^{a}$-IIae q. 47 a. 2 ad 1). Así recupera el pensador la anterior relación de la Sabiduría con la Prudencia, pero no olvida la capacidad electiva que tiene dicha virtud: «la prudencia es meramente cierta rectitud de discernimiento en toda clase de actos o materias» (S.Th. [36084] I'a-IIae q. 61 a. 4 co ). No obstante, anteriormente el pensador Brunetto Latini (ca.1220-1294/1295) ya había reflexionado sobre la Prudencia en su Livre dou Trésor (1260-1266), ${ }^{3}$ donde trata los vicios y las virtudes. En esta obra, siguiendo a Cicerón, define dicha virtud como la sabiduría conocedora del bien y del mal, anteponiéndola a las otras virtudes, a las cuales guía con su luz (Poli, 1999: 49). Con esta definición, el pensador mantiene la capacidad electiva de dicha virtud así como la pone en relación con la luz anteponiéndola a las otras virtudes. Pues es motivo destacable la consideración de la Prudencia como la primera de las virtudes, dándole primacía sobre las demás, lo que vuelve a destacar numerosas veces en los diferentes tomos que componen la obra citada.

3. Obra de tres volúmenes escrita en lengua picarda (es una de las lenguas de oïl, muy próxima al francés). 
Compartiendo dicha consideración, santo Tomás hace referencia a la Prudencia como primera de las virtudes en diversas ocasiones dentro del tratado dedicado a dicha virtud, así como en el que versa sobre las virtudes cardinales (S.Th. [40952] $\mathrm{II}^{\mathrm{a}}$ IIae q.47 a. 4 ad 3, S.Th. [36085] I I -IIae q.61 a. 4 ad 1), por lo que es considerada el principio de todas ellas (S.Th. [40962] $\mathrm{II}^{\mathrm{a}}$ IIae q.47 a. 6 arg. 2). Dicha primacía viene dada por el uso de la razón y su relación con la Sabiduría, consideración que santo Tomás comparte con sus predecesores (S.Th. [36084] I ${ }^{\mathrm{a}}$-IIae q.61 a 4 co). Esta preeminencia se refleja en la imagen visual de la Prudencia, aunque con anterioridad a estas reflexiones, puesto que en la representación de los dones del Espíritu Santo en el relicario del papa Alejandro (ca. 1145, Bruselas, Musées Royaux du Cinquantenaire) encontramos representada a la Prudencia coronada. Aunque existen numerosas representaciones en que las virtudes aparecen coronadas, en esta obra, concretamente, es sólo la Prudencia la que es coronada, distinguiéndola así de las demás.

Tan valiosa es considerada dicha virtud, así como las demás, que Brunetto Latini las asocia con diferentes piedras preciosas. Pues al tratar las virtudes cardinales, empieza por la Prudencia mediante la extraña asociación al rubí (Poli, 1999: 47). El rubí es una piedra que, colocada a lo largo de un corredor sombrío, sirve para guiar el camino, significando, de esta manera, el ojo que ve en la noche. Por este motivo, se le adjudica un tercer ojo a la Prudencia que ve en la noche (Poli, 1999: 49). También con tres ojos la describe Dante (1265-1321), pero dicha asociación está relacionada con el tiempo, por lo que la trataremos más adelante.

Por otra parte, Dante compara las virtudes cardinales con otros objetos brillantes, como son las estrellas (Alighieri, 1995: Purgatorio I, 22-24) o las luces (Alighieri, 1995: Purgatorio XXXII, 97-99). En ambos casos, Dante recoge la idea de Brunetto Latini de relacionar tanto la Prudencia como las virtudes cardinales en sí, con una luz que guía el camino de la vida, compartiendo el mismo fin que la identificación de dicha virtud con el rubí.

Con estos ejemplos vemos que la Prudencia no siempre se representa por sí sola, puesto que al formar parte de las virtudes cardinales, en la mayoría de casos la representación versa sobre la imagen de las cuatro. Pues ante la previa consideración de san Gregorio Magno, quien ya trataba la Prudencia junto a la Templanza, Fortaleza y Justicia, como virtudes morales, santo Tomás las pone en relación destacando la primacía de la Prudencia así como la dependencia de las cuatro (S.Th. [36080] I I -IIae q. 61 a. 4 arg. 1).

Además de las novedades también encontramos continuidad en algunas de las imágenes propuestas anteriormente. Como ya habían mencionado san Ambrosio y san Isidoro, en territorio germano también tuvo lugar la asociación de las virtudes cardinales a los ríos del paraíso. Concretamente en la pila bautismal de Hildesheim (s. XIII, Catedral de Hildesheim) [fig. 8] encontramos representadas estas virtudes como los ríos del paraíso terrestre, con las mismas denominaciones que el Génesis cita. De esta manera la Prudencia se identifica con el Pisón, la Templanza con el Geón, la Fortaleza con el Tigris y, por último, la Justicia con el Éufrates, siguiendo el mismo orden que se indica en el Génesis (Gn. 2,10-14).

Por otra parte, la psicomaquia también se mantuvo. Este tema es característico en los relieves, causa del nuevo impulso hacia la penitencia personal que se produce después del IV Concilio Laterano de 1215, que codificó la dialéctica entre el pecado y la salvación. De la misma forma que los penitentes tienen que ser conscientes de sus vicios y contar todos sus pecados mortales a un confesor al menos una vez al año, los programas de las catedrales los presentan para llevar a cabo una renuncia analítica 


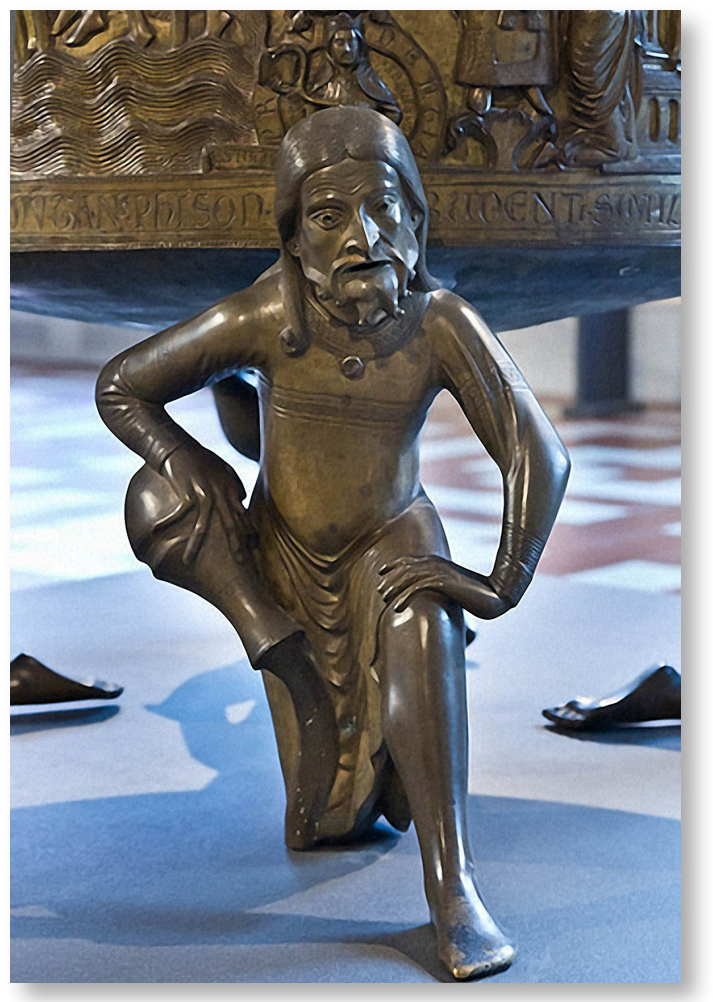

Fig. 8. Prudencia-Pisón, Pila Bautismal de Hildesheim, s. XIII, Catedral de Hildesheimer.

(Camille, 2000: 26). Por estos motivos, los escultores medievales tomaron como referencia la Psycomachia de Prudencio para sus representaciones de los vicios y de las virtudes (Mâle, 1986: 116). Estas últimas, transformadas en amazonas, están casi siempre armadas invariablemente con una lanza (Réau, 1995-2000: 213) y se las suele reconocer por el vicio al que atacan. Aunque son múltiples los ejemplos que da la bibliografía de la representación de dicho combate, ${ }^{4}$ no sabemos ciertamente cuáles de ellos contienen a la Prudencia, puesto que las virtudes y vicios variaban según el lugar.

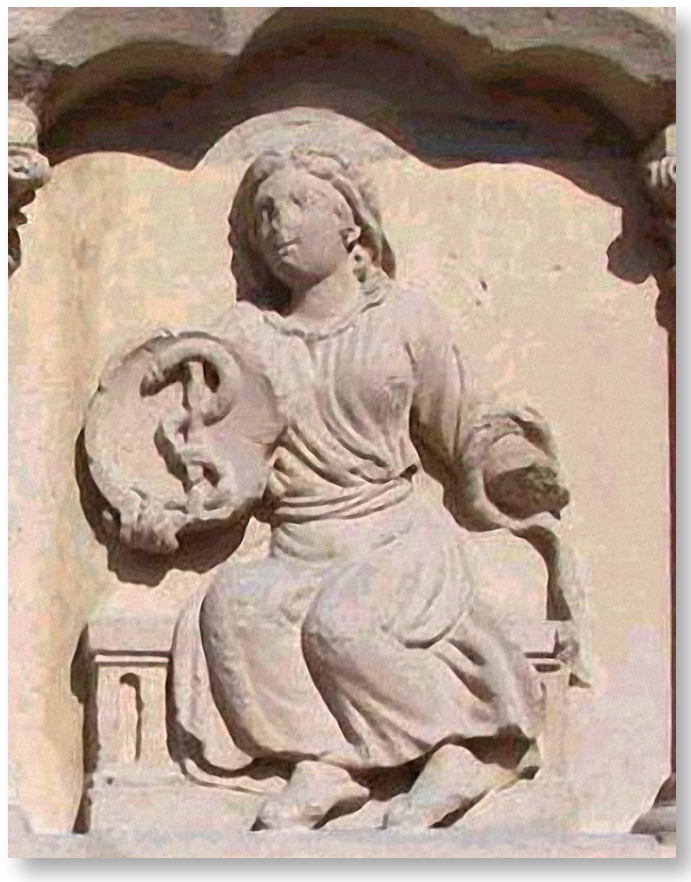

Fig. 9. Prudencia, s. XIII, París, portada central de la Catedral de Notre-Dame.

No obstante su amplio uso, la representación de la psicomaquia como tal desapareció a finales del siglo XIII de la escultura monumental, en el caso francés, para dar paso a nuevas formas, aunque en la zona germana se mantuvo (Réau, 1995-2000: 215). A pesar de la desaparición de la batalla en sí, se conservó la oposición y triunfo de las virtudes sobre los vicios.

Dicha desaparición de la psicomaquia dio lugar a un cambio en el modo de representación, pues en el siglo XIII las virtudes, además de aparecer desarmadas, con blasones heráldicos, triunfantes y entronizadas sobre los vicios, se codifican en siete, distinguiéndose las teologales y las cardinales, ${ }^{5}$ motivo por el cual la represen-

4. Ejemplos: Iglesia de Notre-Dame-Du-Port (Clermont), Catedral de Tournai, Notre-Dame-de-la-Couldre (Parthenay), Saint Hilaire de Melle, Saint Nicolas de Civray, Fenioux de la Charente maritime, Saint Pompain de los Deux-Sècres, Claverley (Shropshire), Copford (Essex), Catedral de Salisbury, fuente bautismal de Stanton Fitzwarren, frescos de Schwarzheindorf, Capilla de San Miguel en Xanten, etc.

5. La cifra de siete se corresponde con las Artes Liberales, no obstante, en ocasiones es ampliada a 12 por situarse en concordancia con los apóstoles, los meses del año o el zodíaco. 


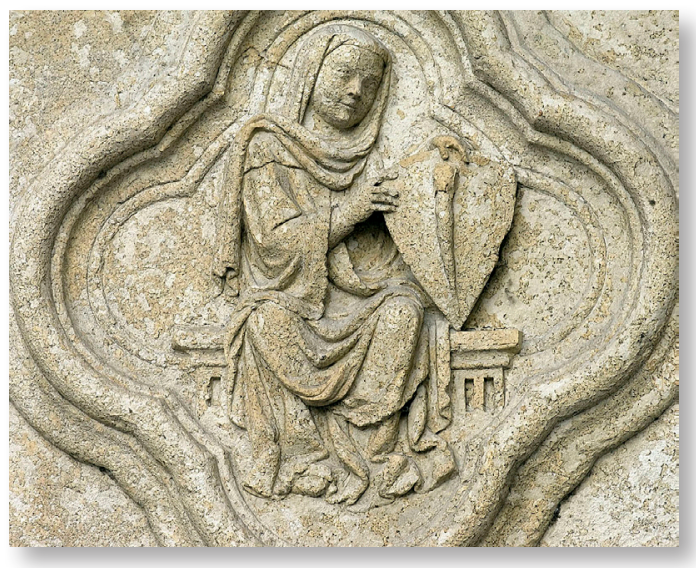

Fig. 10. Prudencia, s. XIII, portada central de la Catedral de Amiens.

tación de la Prudencia es más abundante. La fachada norte de Notre-Dame de París (1136-1245) es el ejemplo más antiguo de este género de representaciones. Fue un artista de París, aconsejado por un teólogo, el que concibió este nuevo programa en los primeros años del siglo XIII. Es en dos lugares distintos donde encontramos representada la Prudencia, en el gran rosetón de la fachada occidental (Mâle, 1986: 117) y en los bajorrelieves inscritos en los cuadrilóbulos que decoran el zócalo de la puerta central [fig. 9], los cuales derivan de los de Amiens (1220-1288, 1366-104), Chartres (1220-1260) y Reims (1211- finales S.s XIII) (Réau, 1995-2000: 218). Tanto en París como en las catedrales mencionadas, la Prudencia lleva un escudo con una serpiente que, a veces, se enreda alrededor de un bastón (Mâle, 1952: 60), cuya presencia ya tiene lugar en el Hortus, anteriormente expuesto. También en Amiens encontramos representada la Prudencia con una serpiente [fig. 10]. Cabe añadir que ya en este siglo encontramos la representación de la Prudencia, así como de las otras virtudes, en el ámbito funerario, como bien muestra la tumba del papa Clemente II (1237, Bamberg) [fig. 11], donde la Prudencia se acompaña de un dragón, encontrando de nuevo la confusión entre ambos animales. Por

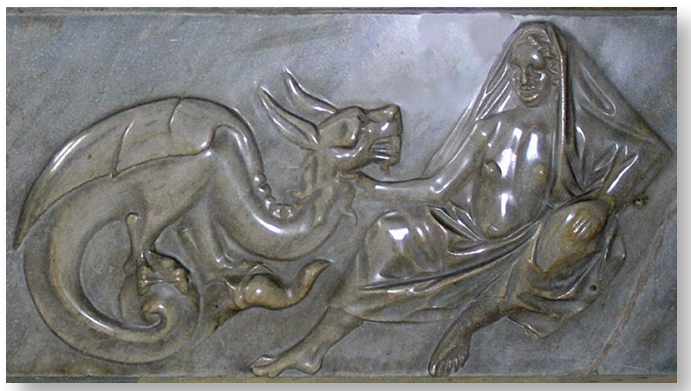

Fig. 11. Prudencia, Tumba del Papa Clemente II (detalle) 1237, Catedral de Bamberg.

tanto, que la Prudencia vaya acompañada de la serpiente se mantiene desde la Antigüedad en las imágenes visuales y literarias así como en las fuentes bíblicas, como se ha expuesto hasta el momento.

Como ya hemos visto anteriormente, en la Antigüedad la Prudencia se relacionaba con el gobernante, tanto en las consideraciones aristotélicas de una «Prudencia política", como en la relación que establece Platón en la República y la asociación de Jano con la imagen de poder. Dicha relación se mantiene en la Baja Edad Media a partir de las reflexiones que realiza santo Tomás partiendo de las consideraciones precedentes (S.Th. [41013] II ${ }^{\mathrm{a}}$-IIae q. 47 a. 12 co). Al poner en relación la Prudencia con el acto de gobernar, santo Tomás explica la vertiente social de dicha virtud en cuanto a su capacidad de consejo y deliberación respecto al bien común (S.Th. [40997] II ${ }^{a}$-IIae q. 47 a. $10 \mathrm{co}$ ).

Mediante estos argumentos y reflexiones que relacionan al gobernante con la Prudencia, santo Tomás llega a la conclusión de que: «La función principal del prudente es aconsejar bien» (S.Th. [41019] II ${ }^{\mathrm{a}}$-IIae q. 47 a. 13 arg. 3). Con todo ello, es propio de cualquier ciudadano, pero sobre todo de cualquier gobernante, la virtud de la Prudencia, con el fin de guiarse bien en el camino de la vida tomando las decisiones correctas, fruto de una buena elección basada en la razón, y a partir de las cuales se podrá dar un buen consejo. Con el fin de vincular 
la Sabiduría, la Prudencia y el Consejo, así como relacionar estos conceptos con el acto de gobernar, la propia Sabiduría afirma en el libro bíblico de los Proverbios lo siguiente: "Yo la sabiduría moro en el consejo, y asisto a los pensamientos juiciosos. (...) Mío es el consejo y al equidad, mía es la prudencia, mía es la fortaleza. Por mí reinan los Reyes, y los legisladores decretan lo justo, por mí los príncipes mandan, y los poderosos decretan la justicia» (Pr. 8,12,14-16).

Es tanta la importancia dada a la posesión de dicha virtud por el gobernante, que la educación de estos se basó en ella. Con este fin nació una literatura moral para príncipes que tenía como objetivo la educación de los mismos bajo los preceptos cristianos así como formas a gobernante prudentes. De esta manera, a partir de los siglos XIII-XIV, en Francia, la reflexión sobre la Prudencia tiene lugar en el desarrollo de una literatura didáctica denominada «espejos de príncipes». Ejemplo de ello es el Livre des faits et bonnes moeurs du roi Charles $V$ le sage de Cristina de Pizan (1364-1430) ${ }^{6}$. En él se expone el arquetipo de soberano ideal evocando la Prudencia como la cualidad esencial del buen gobernante y, proyectando dicha idea fundamentada en las virtudes cristianas en general. Pero esta reflexión no surge con Cristina de Pizan, sino que siempre ha estado presente en la Antigüedad y en la Edad Media que la Prudencia, junto a la Sabiduría, es la virtud que deben poseer los monarcas. Dentro de este discurso ideológico, encontramos una fuerte influencia del pensamiento aristotélico proveniente de sus Éticas. Pues es dato imprescindible saber que fue hacia 1260 cuando tuvo lugar la traducción de la Política y Éticas de Aristóteles a petición de santo Tomás de Aquino. Dicha traducción, realizada por Guillaume de Moerbecke (1215-1286), se completó con comentarios e ilustraciones de las

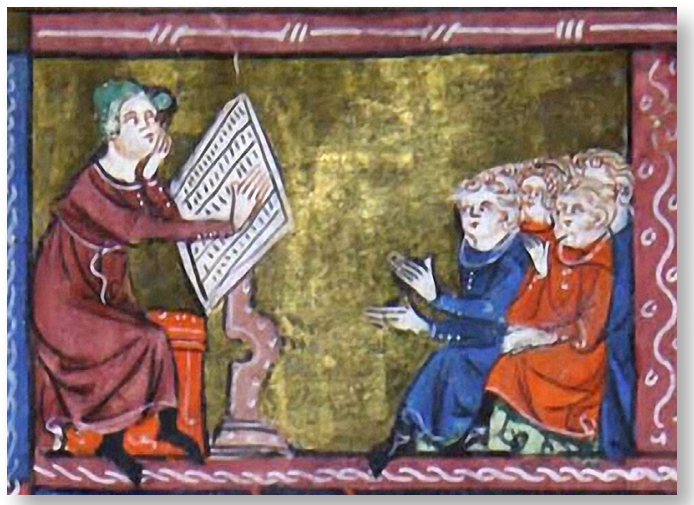

Fig. 12. Prudencia, Somme le Roi (detalle), 1280, Dominic Laurent d'Orleans, fol. 52v.

que tenemos constancia (Chopin-Pagotto, 1999: 88). Pero el espejo de príncipe que fue más novedoso en el momento en materia de reflexión política fue la obra de Gilles de Rome (1247-1316), quien escribió entre 1277-1279 el De regimine principum que será traducido en 1282 para Felipe el Hermoso de Francia (1268-1314), llevando el título Du gouvernement des princes (Chopin-Pagotto, 1999: 90). Esta literatura principesca en que se trata ampliamente el concepto de la Prudencia tendrá continuidad, como veremos más adelante. Gilles de Rome en su obra analiza la Prudencia como una virtud esencialmente política, comparándola a un ojo (Chopin-Pagotto, 1999: 93), el cual guía por el buen camino mediante la visión de lo bueno, capacidad que dota al monarca de guiar a su pueblo por un camino de bondad. Esta comparación nos recuerda a la realizada anteriormente por Brunetto Latini, en la que se comparaba a la Prudencia con un rubí, como ya se ha expuesto.

Cabe destacar que la mayoría de los textos de los «espejos de príncipes» escritos por los grandes retóricos siguen la tradición aristotélica de una Prudencia constituida por una saber experimental (Dauvois, 2012: 56). Un caso semejante del mismo siglo es

6. Existen precedentes carolingios de este género literario como De institutione regia de Jonas d'Orléans (s. IX) y De regis persona et Regio ministerio de Hinemar de Reims (Chopin-Pagotto, 1999: 88). 


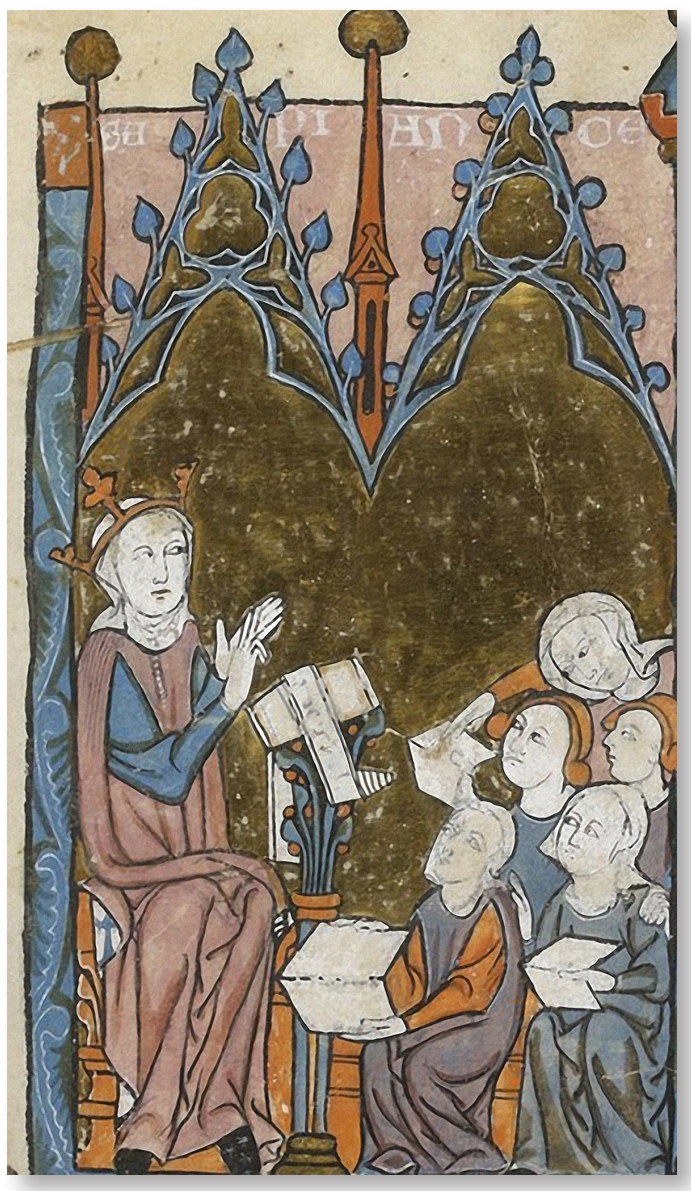

Fig. 13. Prudencia, Somme le Roi (detalle), 1294, Dominic Laurent d'Orleans, fol. 69.

el Somme le Roi (1280) de Dominic Laurent d'Orleans (fl.1279), encargo del rey de Francia Felipe III (1245-1285), presentando un pensamiento instructivo moral y religioso semejante al de Hugo de San Víctor. En esta obra Laurent hace referencia a la Prudencia destacando concretamente su capacidad electiva y de gobierno (Laurent, 1987: 122123). En las ilustraciones de la obra encontramos la representación de la Prudencia portando un libro con el que transmite su saber [figs. 12-13]. En la fig. 13, correspondiente a una edición posterior a la original, la Sabiduría ocupa el lugar de la Prudencia entre las virtudes cardinales, a causa de la relación sinónima que se establece entre

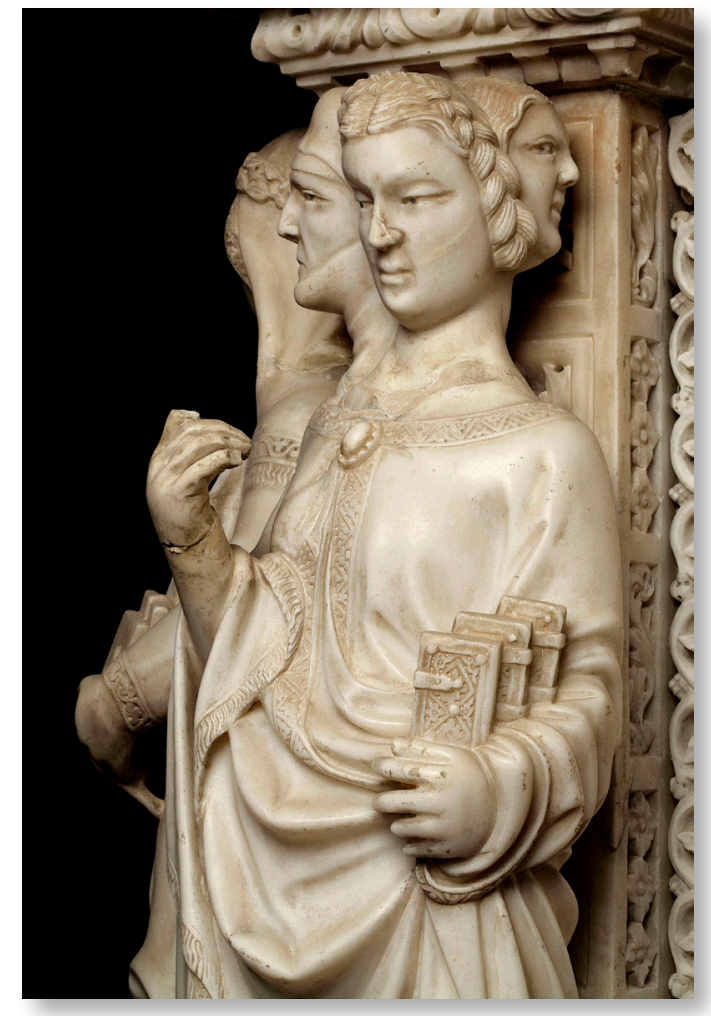

Fig. 14. Prudencia, Arca di Sant'Agostino a Pavia (detalle), s. XIV, San Pietro in Ciel d'Oro.

ambas desde un principio. A dicha relación hace referencia santo Tomás en sus escritos considerando la Sabiduría en sí como propia de Dios, adjudicándole al hombre prudente la Sabiduría humana (S.Th. [40934] II ${ }^{a}$-IIae q. 47 a. 2 ad 1). Así establece una distinción semejante a la realizada anteriormente por Aristóteles, pero añadiendo el componente religioso. Para indicar dicha Sabiduría se representa la Prudencia portando un libro, lo que muestra la continuidad con las imágenes precedentes, ya que el libro es atributo de dicha virtud desde el siglo IX. En el Arca de san Agustín en Pavía (s. XIV, San Pietro in Ciel d'Oro) [fig. 14] así como en la tumba de san Pedro Mártir (1339, Capilla Portinari, Basillica de San Eustorgio, Milán) [fig. 15] encontramos la representación de la Prudencia portando tres libros, en los que se escribe la ciencia universal del tiem- 


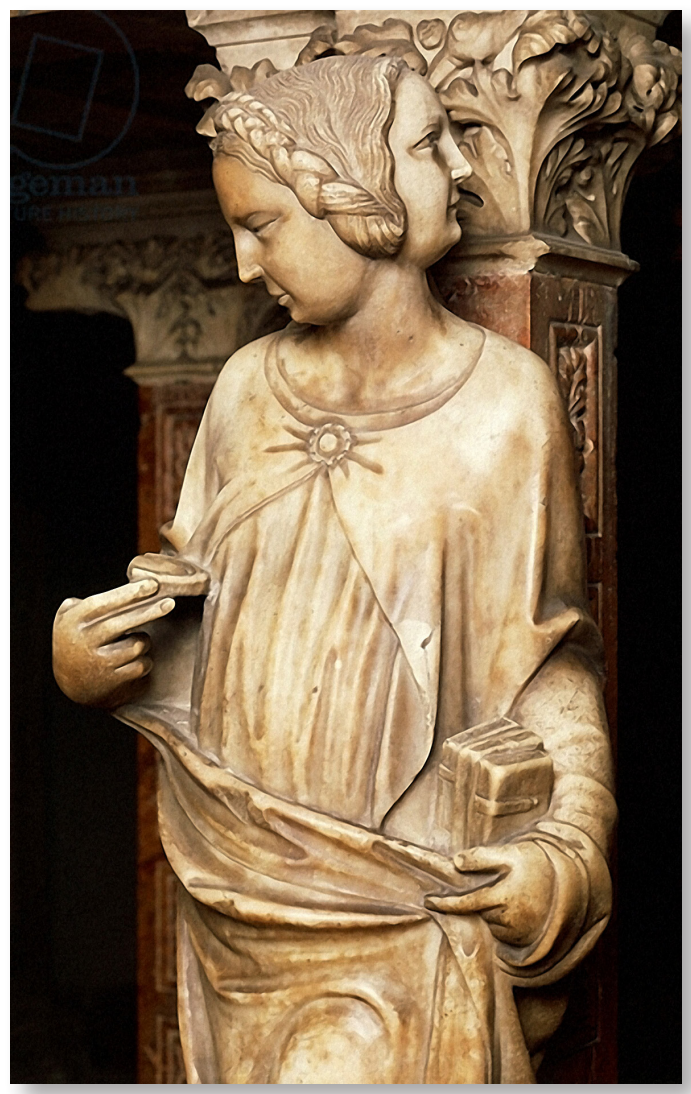

Fig. 15. Prudencia, Tumba de San Pedro Mártir (detalle), 1339, Giovanni di Balduccio, Milán, Basillica de San Eustorgio, Capilla Portinari.

po donde: se narra el pasado, se describe el presente y se previene el futuro. Así mismo ambas obras se completan con 3 caras, con el fin de que cada una de ellas pueda leer el libro correspondiente al tiempo que hace referencia. Además, en la obra milanesa, el rostro que mira hacia el norte corresponde a un religioso, más viejo y arrugado, frente a la faz orientada hacia el nordeste más joven, referente al presente, y contrastando ambas con la cara sureste, el futuro, más joven aún que las anteriores y con el cabello suelto (Ainé, 1850: 54-55). No obstante el aparecer tres libros, en muchas ocasiones se condensan en la representación de uno

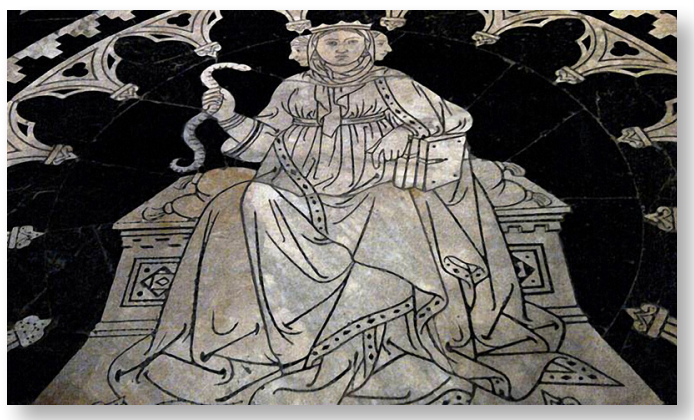

Fig. 16. Prudencia, pavimento de la catedral de Siena (detalle), s. XIV.

sólo, siendo el caso del mayor número de obras, como se ha visto hasta el momento. Además de estos casos encontramos otras obras, contemporáneas a las anteriores, que presentan características semejantes: la Prudencia representada en el pavimento de la Catedral de Siena (s. XIV) [fig. 16] y la Prudencia de Bonino di Campione (ca.13571397, National Gallery of Art, Washington) [fig. 17]. Ambas representaciones de dicha virtud comparten la presencia del libro así como de varios rostros. En el primer caso encontramos la permanencia de la serpiente, ejemplo de la continuidad de dicho atributo. Tanto la multiplicidad de rostros como de libros explican la relación de la Prudencia con los estados del tiempo y la experiencia, asunto ya tratado desde la Antigüedad.

Dicha relación de la Prudencia con el tiempo es retomada por Brunetto Latini, quien realiza una tripartición de dicha virtud con dicho fin: "Si tú eres hombre sabio, tú debes ordenar tu coraje según tres años de esta manera: tú ordenarás las cosas presentes, prevendrás las que vendrán, y te acordarás de las que son pasadas" (Cfr. Poli, 1999: 50). Así mismo, «la prudencia consiste en la recordación del pasado, la ordenación del presente y la contemplación del futuro", como podemos leer en el Repertorium morale de Petrus Berchorius (1290-1362) ${ }^{7}$. Santo Tomás también hace referencia a este

7. «in praeteritorum recordatione, in praesentium ordinatione, in futurorum meditatione». Según Panofsky, Berchorius se 


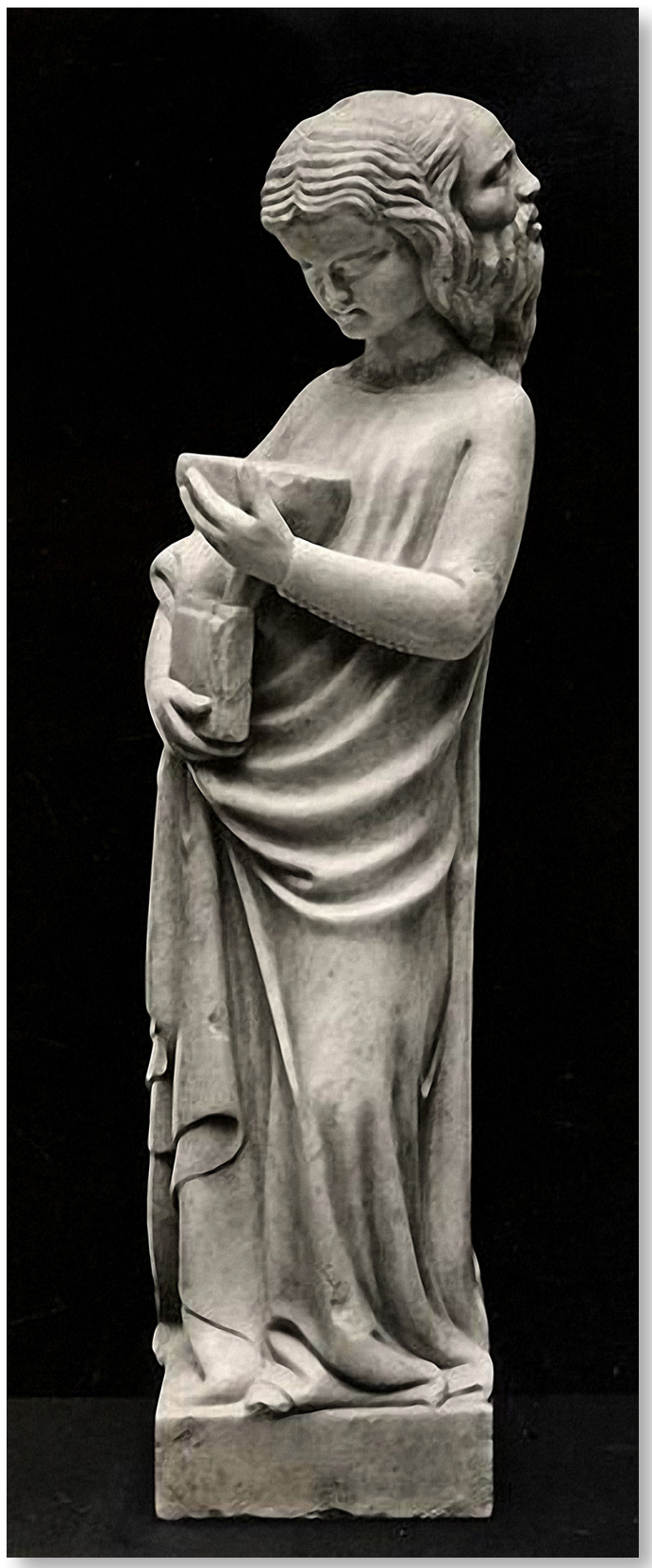

Fig. 17. Prudencia, ca.1357-1397, Bonino di Campione, Washington, National Gallery of Art. aspecto en consideración a dicha virtud poniéndola en relación con los diferentes estados del tiempo, en cuanto a que son tenidos en cuenta como fundamento del acto pru-

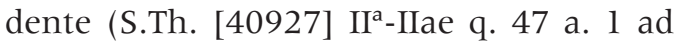
2). Por tanto, la Prudencia se adquiere con el paso del tiempo mediante la experiencia y la educación, aspecto también tratado por santo Tomás (S.Th. [41032] II ${ }^{\mathrm{a}}$-IIae q. 47 a. 14 ad 3) siguiendo en diversas ocasiones las reflexiones de Aristóteles.

Como hemos visto, desde la Antigüedad, la referencia al tiempo en la personificación de la Prudencia se manifiesta mediante la representación de diversos rostros. El doble rostro, en el que se distingue la edad, proviene del don que Macrobio atribuye a Jano de conocer el pasado (rostro de hombre mayor) y de prever el futuro (rostro de mujer joven), que hizo a la vez de la cabeza bifronte un atributo de la Prudencia. De esta manera, la bifrontalidad define, ya desde época romana, la imagen del dios Jano, lo que hemos visto anteriormente con Ovidio y Macrobio. Esta peculiaridad pervive en la Baja Edad Media, cuando la encontramos referenciada en el siglo XIII en el Roman de la rose (1225-1240, Guillaume de Lorris, 1275-1280, Jean de Meung, v.827-832) donde es descrita dicha virtud con aspecto bifaz (Maupeu, 2012: 42). Aunque esta referencia es francesa, los primeros ejemplos visuales de la bifrontalidad de la Prudencia pertenecen al ámbito italiano. Es en el siglo XIV, con Giotto (1267-1337), cuando el arte italiano se desvincula de la imitación francesa y aporta nuevas fórmulas de representación. Se piensa que Giotto conoció los modelos franceses, o bien de visu, o bien, lo más probable, a través de dibujos o bajorrelieves portátiles de pequeño tamaño realizados en marfil. Pues las alegorías y los vicios que Giotto pintó en grisalla, a imitación de

refiere al Liber de moribus de Séneca, pero la fórmula citada aparece en un tratado titulado Formula vitae honestae o De quattor virtutibus cardinalibus, que también se atribuía a Séneca y se solía imprimir junto con el Liber de moribus, con todo ello se considera que el autor del primero fue el obispo Martín de Braga. Este libro del obispo bracarense es el tomado, a su vez, como referencia, por Cristina de Pizan para realizar su propia obra.

IMAGO, NÚM. 6, 2014, 97-I I6 


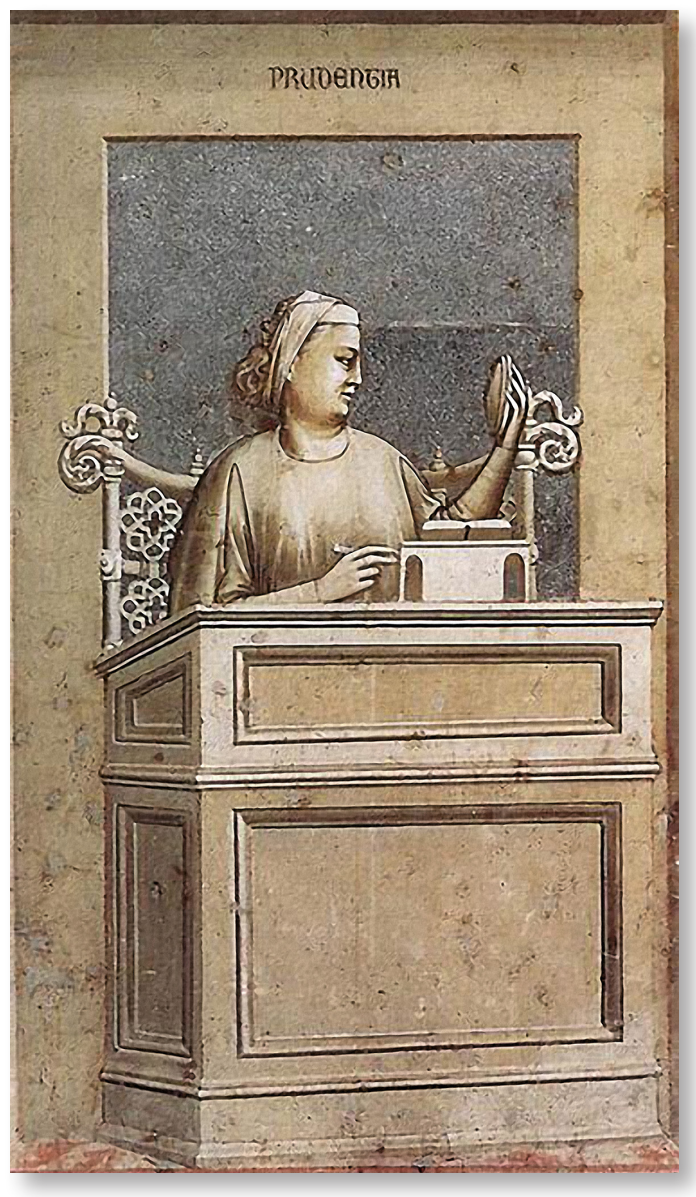

Fig. 18. Prudencia, 1305, Giotto, Capilla Scrovegni (detalle), Padua.

esculturas o de piedras grabadas, en la parte inferior de los frescos de la Capilla Scrovegni (1305, Padua) [fig. 18] recuerdan, por su emplazamiento a los cuadrilóbulos del zócalo de las portadas de Notre-Dame de París y de Amiens [fig. 16-17]. En estos frescos aparece representada la Prudencia con nuevas características: bifaz, con un espejo y un libro. La bifrontalidad y el libro ya han sido expuestos, pero el espejo se presenta como novedad. Este atributo sirve para conocerse a sí mismo y regular las propias acciones, partiendo del conocimiento de los propios defectos, así como hace referencia a la circunspección (Woodford, 1953: 524). Así pasó el aspecto del dios

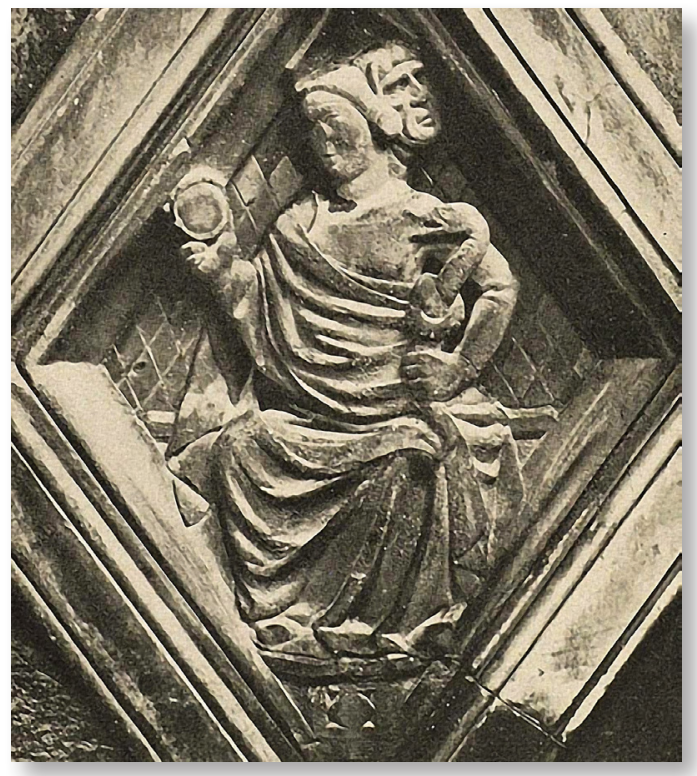

Fig. 19. Prudencia, 1337-1348, Andrea Pisano, Campanille del Duomo de Florencia (detalle).

Jano y su fisionomía, ya moralizada, a ser la imagen de la Prudencia, tal y como muestra la obra citada así como el campanille de la Catedral de Florencia (1337-1348) [fig. 19]. También en la literatura francesa encontramos una de las representaciones más antiguas del doble rostro. En Le peregrinage de vie humaine de Guillaume de Digulleville (ca.1330-1331, v.4905-4908) la Prudencia se presenta como un arma defensiva que protege al peregrino, caracterizándose por la Providencia y la Memoria representada por el doble rostro (Maupeu, 2012: 44-45).

La referencia al tiempo, además, es significativa en su representación en el ámbito civil, tendencia que surge en Italia en el siglo XIV. El ejemplo más destacado es la Alegoría del Buen Gobierno de Ambroggio Lorenzetti (1338-1339, Palacio Publico de Siena), donde la Prudencia se muestra sosteniendo un disco cuyos tres sectores llevan las inscripciones "Tempus praeteritum», «Tempus praesens» $\mathrm{y}$ "Tempus futurum» atribuidas a Séneca y expuestas anteriormente, o un brasero del que brotan tres llamas rotuladas de modo análogo [fig. 20]. No obstan-

IMAGO, NÚM. 6, 2014, 97-II6 


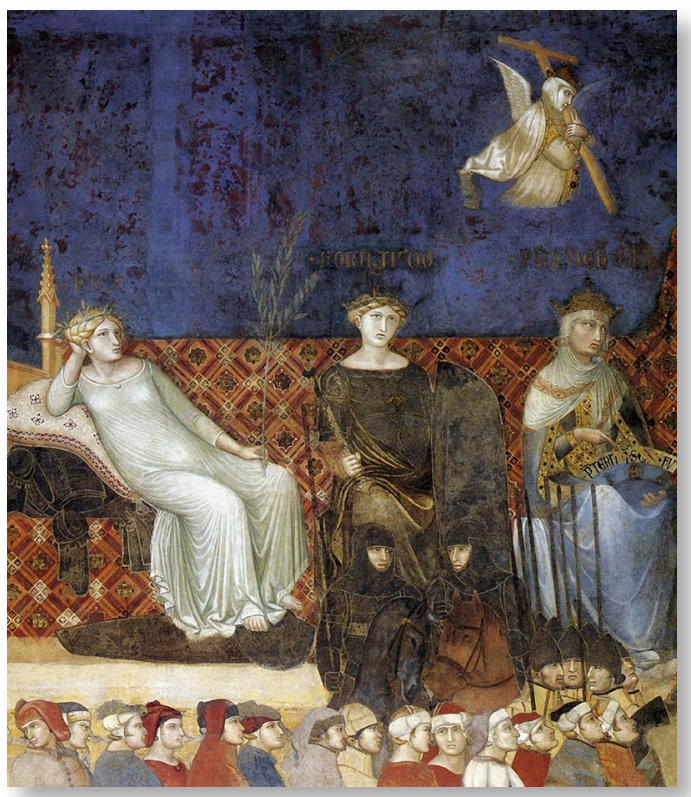

Fig. 20. Paz, Fortaleza y Prudencia, El buen gobierno (detalle), 1338-1339, Ambroggio Lorenzetti, Palacio Público de Siena.

te, además de las inscripciones referentes al tiempo y la representación bifaz o trifaz, encontramos más imágenes que hacen referencia a dicha relación. Dante, siguiendo a su maestro Brunetto Latini identifica a la Prudencia con tres ojos (Poli, 1999: 49). De esta manera la Prudencia dantesca presenta 3 ojos en lugar de tres caras, aunque con el mismo significado: "A la izquierda otras cuatro hacían fiesta con túnica de púrpura: abre danza la que luce tres ojos en la testa" (Alighieri, 1995: Purgatorio XXIX, 130 132). Estos tres ojos representan las tres partes de la que se compone la Prudencia, siendo situado, frecuentemente, el tercer ojo en la parte trasera de la cabeza, queriendo significar la Memoria (Poli, 1995: 50). Por tanto, la Prudencia trata de conocer, mediante sus diversos rostros y ojos, los tres estados del tiempo, tomando la experiencia del pasado para aplicarla al presente según lo que prevé en el futuro. No obstante, en las tres dimensiones encuentra un punto en común, la muerte. Por este motivo, una de las miniaturas de la Ética de Aristóteles, atri-

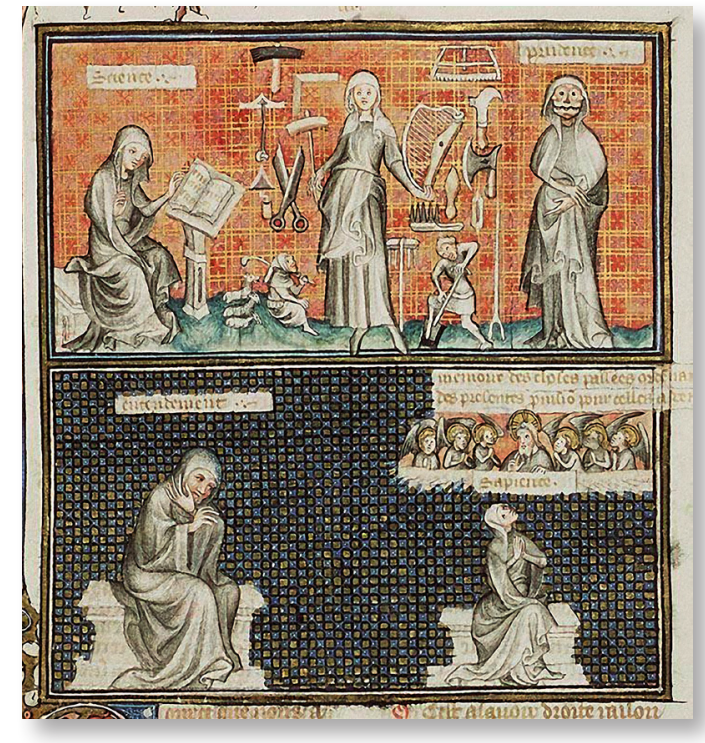

Fig. 21. Ciencia, Arte y Prudencia, Ética de Aristóteles (detalle), 1376, Koninklijke Bibliotheek.

buida al llamado Maestro de la Coronación de Carlos VI [fig. 21], muestra la Prudencia como una figura con un triple rostro de calaveras, cada una mirando a una de las direcciones del tiempo. Aunque la imagen no permite ver con claridad los tres rostros, se aprecia su presencia por la protuberancia de la nariz de las caras laterales (Richter, 1995: 127). Esto significa que la Prudencia, al conocer las dimensiones del tiempo es consciente de que sus decisiones y acciones le pueden llevar a la muerte, puesto que es allí donde acabará en un futuro, pero la cual puede precipitarse en el mismo presente sino actúa prudentemente.

Las diversas caras, además del tiempo hacen referencia a las partes que los pensadores designan a la Prudencia. Santo Tomás atribuye a la Prudencia las seis que le asigna Macrobio, más la "memoria» que aporta Cicerón, y la «sagacidad» que añade Aristóteles, lo que santo Tomás explica de la siguiente manera: "De estas ocho, cinco pertenecen a la prudencia como cognoscitiva: la memoria, habilidad en el raciocinio, inteligencia, docilidad y sagacidad; y tres a la prudencia como preceptiva, a saber: la 


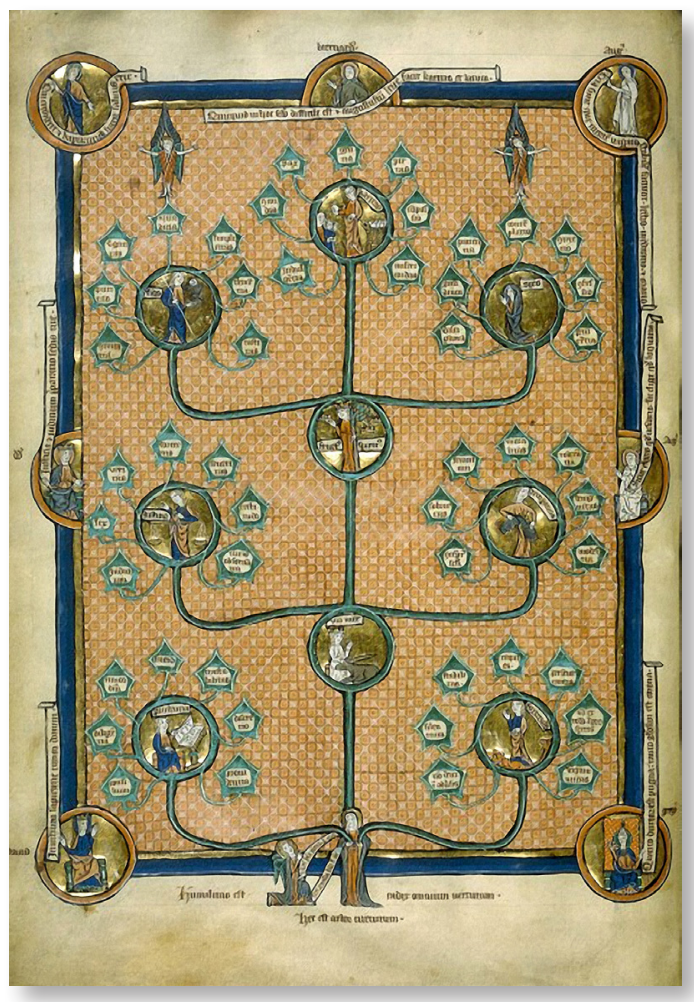

Fig. 22. Árbol de las virtudes, Speculum theologiae (detalle), s. XIII, París, Bibliothèque nationale de France, Département des Manuscrits, Division occidentale, Français 9220, fol. 5v.

previsión o providencia, la circunspección y la precaución» (S.Th. [41055] II ${ }^{a}$-IIae q. 48 co ). Estas partes, a veces, tienen su correspondencia visual mediante atributos de la Prudencia. Es el caso del aspecto bifaz que, además de hacer referencia al tiempo, representa la Memoria (en su cara posterior) como recuerdo del pasado así como la Providencia (en su cara frontal) como previsión del pasado. Las partes citadas tienen personificaciones por sí mismas en las que comparten características o atributos con la imagen de la Prudencia, lo que podemos observar a partir del s. XVI.

También en relación con dichas partes se representa el árbol de las virtudes. Pues este árbol muestra siete ramas en las que se inscriben las siete virtudes, portando cada una

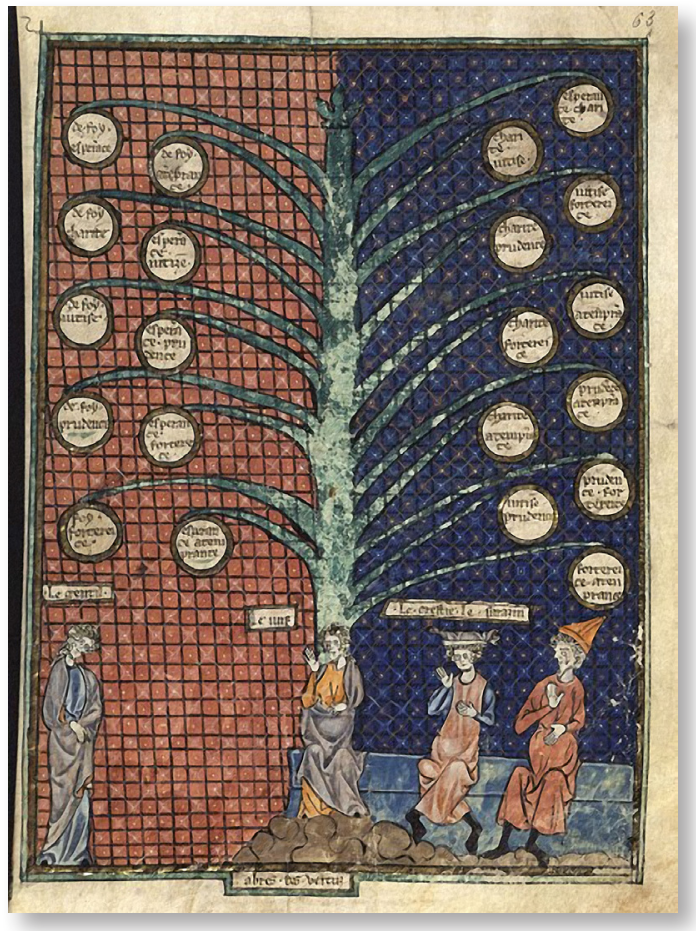

Fig. 23. Árbol de las virtudes, Llibre del gentil e dels tres savis, s. XIII, Ramon Llull, Bibliothèque nationale de France, Departamento de Manuscritos de la División Occidental, Français 22933, fol. 63/64.

al mismo tiempo siete hojas en las que se citan las correspondientes partes de cada una. Es ejemplo de ello el árbol de las virtudes ilustrado en el speculum theologiae (s. XIII, Ms. 9220, fol. 5v, Bibliothèque Nationale de France, Département des Manuscrits, París) [fig. 22]. No obstante, no todas las representaciones incluyen la distinción realizada por santo Tomás de las siete virtudes (teologales y cardinales) sino que incorporan muchas más creando árboles de virtudes diversos. Muestra de ello es una ilustración de dicho árbol en el Llibre del gentil e dels tres savis de Ramon Llull (s. XIII, Ms. 22933, fol. 63/64, Bibliothèque Nationale de France, Departamento de Manuscritos de la División Occidental, París) [fig. 23].

La representación de árboles no sólo se usó como imagen clasificadora de las virtudes sino también de los vicios y las artes 


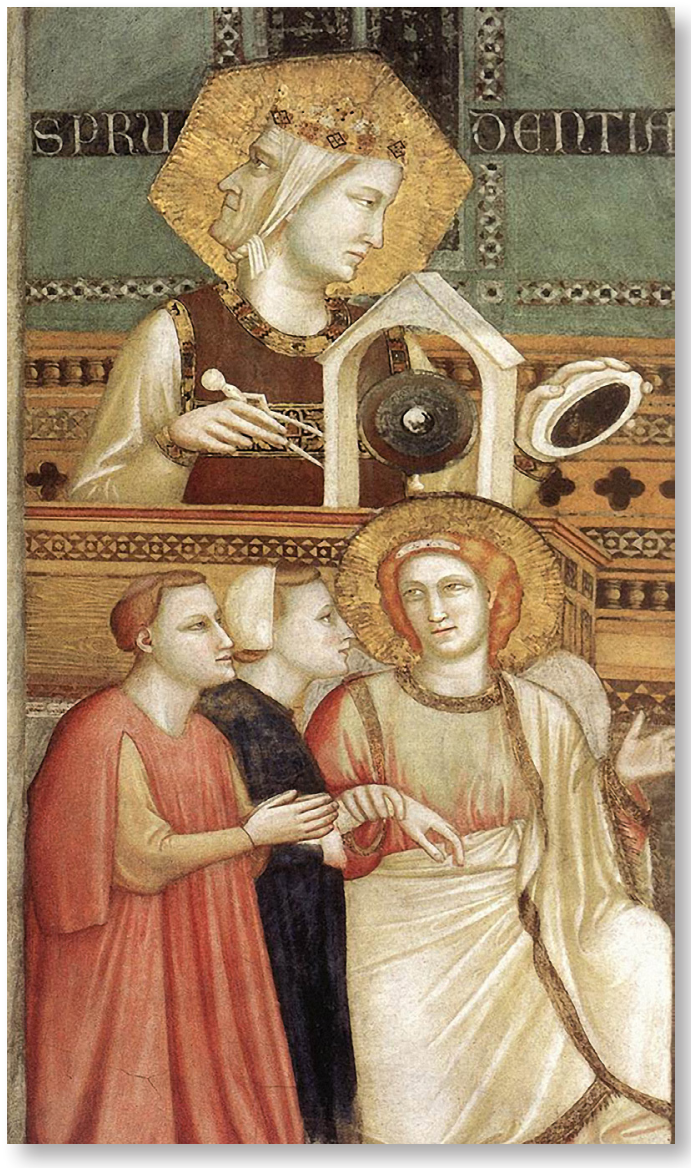

Fig. 24. Alegoría de la Prudencia, 1291-1292, Giotto, Iglesia superior de San Francisco de Asís (detalle).

liberales entre otras. Ello llevó a relacionar las artes liberales con las virtudes, tomando éstas últimas atributos de las primeras. A partir de estas premisas, encontramos la representación de la Prudencia portando un compás, atributo con el que toma las justas medidas, como muestran las alegoría de dicha virtud representada en la Iglesia Superior de San Francisco de Asís (Giotto, 1291-1292) [fig. 24]. En esta obra la Prudencia también se acompaña de dos caras y un espejo, atributos expuestos anteriormente. Aunque en este caso es representado un compás, son múltiples los atributos de la Prudencia que son instrumentos de medida, compartiendo el mismo significa-

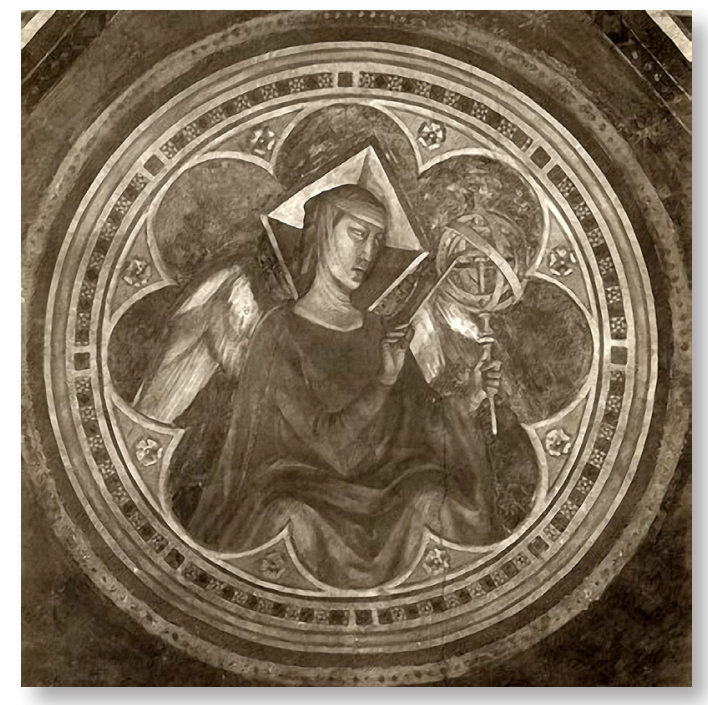

Fig. 25. Prudencia, s. XIV, Taddeo Gaddi, Iglesia de la Santa Croce (detalle), Florencia.

do. Por este motivo, en ocasiones se representa con regla, vara, escuadra, cartabón, transportador o disco, etc. No obstante, en la Baja Edad Media, el uso de instrumentos de medida para la imagen de la Prudencia es escaso, lo que cambiará a partir del siglo $\mathrm{XV}$, momento en que encontraremos abundantes imágenes con estas características. También de la conjunción de las artes liberales con las virtudes deriva la imagen de la Prudencia portando una esfera armilar. En los frescos de la Santa Croce de Florencia de Taddeo Gaddi (ca.1328) [fig. 25] donde la Prudencia aparece representada con doble rostro y una esfera armilar, creando una alegoría compleja en la que a cada virtud se le unen los atributos de una de las artes, como ya se ha explicado. Ya entonces se asociaban las virtudes a las artes, planetas y metales, como se hará más adelante (Esteban, 1990: 406-407).

Por tanto, la Baja Edad Media supone un amplio campo de experimentación en el ámbito imaginario en el que confluyen las tradiciones clásicas con las medievales. Fruto de ello es la permanencia de la concepción filosófica de los pensadores así como de 
algunos atributos tomados de los dioses paganos. Además de la continuidad, comienza a haber un amplio campo de variación en el que encontramos mayor correlación entre las imágenes literarias y visuales así como con el pensamiento. No obstante, no son sólo éstas todas las variantes en las que se representa la Prudencia, sino que seguirán surgiendo nuevos atributos y reflexiones en los siguientes periodos.

\section{BIBLIOGRAFÍA}

AINÉ, D. [1850]. "Iconographie des quatre vertus cardinales», Annales Archéologiques, París, Libraire Archéologique de Victor Didron, 40-56.

CAmes, G. [1971]. Allégories et symboles dans l'hortus deliciarum, Leiden, E. J. Brill, 5473.

LEÓN COLOMA, M.A. [1989] «Iconografía de la Prudencia en España durante los siglos XV y XVI", Cuadernos de arte de la Universidad de Granada, 20, 65-78.

MÂLE, E. [1986]. El Gótico: la iconografía de la Edad Media y sus fuentes. Madrid, Encuentro, 115-149.

MARLE, R. VAN. [1971]. "L'allêgorie êtique», Iconographie de l'art profane au Moyen-Age et à la Renaissance et la décoration des demeures, New York, Hacker Art Books, 2, 1-103.

MAupeu, P. [2012]. "Les aventures de Prudence, personnage allégorique, $\mathrm{V}^{\mathrm{e}}-\mathrm{XV}^{\mathrm{e}}$ siècle». En: Berriot-SAlVATORE, E. et al. La vertu de prudence: entre Moyen Âge et âge classique, París, Classiques Garnier, 3354.

Poli, L. [1999]. "Formes de la Prudence de Brunetto Latini à Dante», La Représentation de la Prudence, Chroniques Italiennes, París, Université de la Sorbonne Nouvelle, 60, 45-56.

RÉAU, L. [1995-2000]. Iconografía del arte cristiano, Barcelona, Serbal, 197-229. 